\title{
Komunikasi Getok Tular Pengantar Popularitas Merek
}

\author{
Rudy Harjanto dan Deddy Mulyana
}

\begin{abstract}
Word of mouth (WOM) is a self-spreading chained series of communication in a certain community. The term 'mouth' was derived from the fact that the mode of message delivery in WOM is mainly orally, informally, and personally - reflecting the ways we had been talking each other in daily conversation. Technological advance has broadening the scope of WOM. Through the Internet, WOM appears in many digital communication features such as website, online profile pages, personal blog postings, and of course, exchanging mails. WOM, in many ways, has enriched conversation content by exchanging information, knowledge, views, and so on. In a collectivist society like Indonesia, WOM melted - in fact integrated within families (family, clans, working class, etc.). Traditionally, WOM occured when people interested in certain topic. As a form of communication, WOM could be developed as reference channel to popularize a brand (product). This is due because audience believe more to message delivered by somebody they know or respected by them.
\end{abstract}

Kata kunci: komunikasi, mulut ke mulut, kolektif, popularitas.

Komunikasi getok tular (Word of mouthWOM) adalah komunikasi berantai yang beredar dengan sendirinya di suatu komunitas tertentu. Seseorang menyampaikan pesan kepada seseorang, kemudian pesan itu bergerak karena orang tersebut kemudian menyebarluaskan pesan tersebut. Komunikasi dari mulut ke mulut (wordof-mouth communication) merujuk pada penyampaian informasi yang pada umumnya dilakukan secara lisan, informal, dari seseseorang kepada orang lain secara pribadi, antara dua individu atau lebih. Interaksi antara dua individu yang secara aktif ini, menunjukkan aktivitas proses komunikasi yang dinamis. Proses komunikasi, menurut Dance (Littlejohn, Foss:2008) seperti halnya semua proses sosial, terkait dengan pengaruh lingkungan, yang pada dasarnya secara terus-menerus berubah, sehingga membentuk sebuah proses komunikasi dinamis secara alamiah. Dinamika proses ini membentuk pusaran (helical model) yang mendeskripsikan bahwa setiap aspek berbeda sejalan dengan proses berjalannya waktu. Pada satu percakapan, misalnya, topik dan arah melebar sejalan dengan pengetahuan para pelaku komunikasi terkait.

Pertukaran informasi dalam komunikasi getok tular sebagai bagian dari komunikasi antarpribadi, dapat dilakukan secara tatap-muka maupun melalui telepon, pengiriman pesan singkat (Short Message Service-SMS). Perkembangan teknologi memungkinkan komunikasi getok tular juga berkembang melalui internet, situs web, maupun 
halaman-halaman profil online, posting dalam blog-blog pribadi maupun pertukaran informasi melalui email. Orang-orang memperkaya isi percakapan dengan informasi, pandangan, pengetahuan, dan sebagainya, secara terusmenerus. Isi komunikasi yang saling dipertukarkan akan memengaruhi struktur dan isi komunikasi yang akan terjadi, sehingga komunikasi tersebut bersifat positif.

Mengacu pada pendapat Dance, sebuah komunikasi pada suatu kondisi yang berbeda, akan membentuk garis pusaran yang akan berbeda pula. Dalam beberapa hal, garis pusaran cenderung sangat melebar, yang disebabkan oleh luasnya pengetahuan maupun topik. Jika pelaku komunikasi memiliki pengetahuan yang terbatas, garis pusaran pun mengecil. Model komunikasi ini memberikan pemahaman bahwa dalam beberapa hal, komunikasi tidak selalu bersifat linear atau sirkular. Proses komunikasi bergerak maju, para pelaku komunikasi adalah mereka yang aktif, kreatif, serta mampu menyimpan dan menggunakan informasi. Bukan seperti model linear yang berpendapat bahwa khalayak sasaran komunikasi atau komunikate (yang oleh sebagian kalangan disebut sebagai komunikan) sebagai individual yang pasif.

Oleh karena itu, komunikasi getok tular berkembang dan menjadi tumpang tindih dalam penyebaran informasi secara pribadi secara lisan, dengan kabar angin, gosip, sindiran, dan desas desus. Saluran informasi informal dalam organisasi sering diberi cap "desas-desus" (rumor) dan "selentingan" (grapevine). Istilah "grapevine" muncul pada masa Perang Saudara di Amerika Serikat. Pada masa itu, saluran telegram intelejen disambung-sambungkan secara longgar dari pohon ke pohon seperti rangkaian tanaman anggur (grapevine). Tanaman terlihat tumbuh dan menjalar ke segenap arah, menangkap, dan menyembunyikan buahnya di bawah rerimbunan dedaunan, nyaris tanpa adanya undangan untuk melakukan penyelidikan lebih lanjut.

Kiasan ini menggambarkan bahwa pesan yang menjalar ke segenap arah ini tidak dapat dikendalikan sepenuhnya, tidak diketahui sumbernya secara resmi dan mengakibatkan pesan yang disampaikan seringkali menjadi sulit dilacak. Jadi, setiap desas-desus dianggap berasal dari "grapevine" atau "sebuah proposisi untuk dipercaya ... tersebar tanpa pembuktian resmi”. Desas-desus mengurangi ketegangan emosional dan biasanya timbul dari lingkungan yang ambigu. Lingkungan yang ambigu ini menciptakan kondisi tertentu tentang kebutuhan dan keinginan seseorang. Kondisi ini dimanfaatkan oleh pemasar untuk memberikan informasi yang sebenarnya, sehingga khalayak sasaran menyadari kebutuhan yang sebenarnya. Untuk menyampaikan informasi ini pemasar menggunakan pemasaran dari mulut ke mulut atau komunikasi getok tular.

Aktivitas komunikasi getok tular dalam komunikasi pemasaran berkembang layaknya sebuah aktivitas teatrikal secara alami. Para pemasar mengungkapkan informasi tentang produk atau layanan kepada kalangan terbatas di antara sebaran khalayak sasaran. Secara khusus, para pemasar menggunakan pendekatan satu per satu melalui pertukaran informasi secara pribadi kepada para tokoh panutan khalayak, dan memengaruhinya. Pengaruh yang telah tertanam pada para tokoh panutan dengan sendirinya menciptakan suatu kampanye lisan yang canggih, sehingga para khalayak di sekitar tokoh panutan tersebut ikut tercakup untuk termasuk kelompok para tokoh panutan mereka dan dengan sepenuh hati menyebarkan informasi kepada para sahabat dan para rekan kerja mereka. Mereka dengan senang hati menyebarluaskan pesan karena mereka mendapatkan sesuatu untuk dibicarakan. Kunci yang memungkinkan pesan beredar di antara para anggota komunitas adalah pesan yang menarik perhatian dan memberi mereka rasa nikmat saat mereka membicarakannya. Saat berbagi pesan dengan dengan orang lain, mereka menghibur orang lain, kelihatan lebih pintar atau cerdik, dan terlibat dengan pesan tersebut (Hughes, 2005).

Komunikasi getok tular adalah salah satu bentuk komunikasi yang para pelakunya saling bertukar lambang-lambang dan pemaknaan. Tindakan menyampaikan dan menerima pesan berlangsung timbal balik, sehingga terjadi kesamaan pemahaman di antara mereka terhadap 
pesan yang digunakan dalam proses tersebut. Komunikasi getok tular adalah substitusi berita yang telah diverifikasi dalam sebuah komunitas, dan merupakan suatu transaksi kolektif yang melibatkan komponen intelektual dan komunikatif; yang berkembang sebagai usaha individu dalam suatu kelompok untuk mengatasi suatu kondisi yang ambigu. Komunikasi getok tular adalah suatu bentuk transaksi secara bersama-sama di dalam sebuah komunitas untuk mengkonstruksikan penafsiran atas hakikat suatu keadaan.

Kebersamaan di dalam komunitas sebenarnya sangat tergantung pada kaitan hubungan di antara sesama anggota komunitas dengan teman-teman dalam lingkungan dekat mereka. Mereka yang memiliki ikatan kuat, mempunyai motivasi yang lebih kuat untuk saling percaya, saling membantu dan lebih siap membantu satu sama lain. Semakin kuat hubungan, semakin tinggi tingkat kepercayaan yang tercipta, dan semakin kuat dukungan yang diberikan. Dalam proses komunikasi getok tular ini, komunikator menyampaikan pesan secara langsung kepada khalayak sasaran yang umumnya merupakan sebuah komunitas. Anggota komunitas pada gilirannya juga menjadi komunikator yang menyampaikan pesan kepada komunitas lainnya, dan begitu seterusnya.

Pesan yang tersebar dalam perbincangan ini berasal dari satu sumber yang tidak diketahui secara resmi. Meskipun isi pesan menjadi konsumsi publik dan berfungsi sebagai substitusi informasi resmi, sumber rumor tidak pernah resmi diperkenalkan. Oleh karena itu, rumor biasanya diawali dengan kata-kata yang mencerminkan sumber yang tidak diketahui seperti penggunaan kata "katanya". Pemahaman "katanya" ini kemudian secara gradual menghilang dan rumor berkembang menjadi bahan perbincangan pokok dan menjadi pesan. Pesan dalam hal ini adalah perbincangan di dalam aktivitas komunikasi getok tular yang merupakan suatu upaya kolektif untuk menemukan kesepakatan tentang topik tertentu.

\section{Komunikasi Getok Tular dalam Aktivitas Pemasaran}

Beberapa perusahaan melakukan pendekatan kepada konsumen dan calon konsumen potensial secara terstruktur dan fungsional. Mereka mulai mengubah pola beriklan tradisional di media massa seperti suratkabar, majalah, radio, iklan luar ruang (outdoor), dan televisi, dengan menggunakan pola komunikasi yang menimbulkan efek perbincangan dari mulut ke mulut, melalui aktivitas penyebaran pesan secara viral, melakukan pertukaran informasi secara pribadi dan spontan sebagai pelengkap aktivitas komunikasi pemasaran, untuk menyampaikan keunggulan produk-produknya maupun mengatasi kelemahan produk-produk di dalam aktivitas pemasaran mereka. Misalnya, informasi kegagalan dalam meluncurkan New Coke menjadi perbincangan di dalam khalayak para pecinta minuman berperasa Cola (Haig: 2003). Alihalih beredarnya informasi kegagalan yang bersifat negatif, kegagalan tersebut yang menjadi pembicaraan dari mulut ke mulut memberikan dampak positif. Perbincangan yang terjadi adalah kinerja Coca-Cola. Coca-Cola sangat serius untuk memberikan tanggapan terhadap reaksi khalayak dan pasar sasaran. Begitu juga Cadburry (Kotler, et. al.: 2003) yang menggunakan pendekatan harga dalam usaha untuk mengatasi persaingan dan merebut hati serta mempengaruhi pemikiran khalayak. Strategi penurunan harga dilakukan untuk mempertahankan pangsa pasar yang telah ada secara optimal, sehingga strategi ini menjadi bahan pembicaraan dari mulut ke mulut dan beredar luas.

Berbeda dengan Cadburry, perancang busana Vera Wang (Morgan: 1999) berhasil membangun perbincangan dari mulut ke mulut dengan membuat terobosan baru dalam peluncuran koleksi terbarunya . Alih-alih membuat gala show seperti yang dilakukan para perancang busana. Ia melakukan terobosan baru dengan memproduksi sebuah buku pencitraan (image book), yang dipenuhi foto para model yang mengenakan dua lusin koleksi gaun rancangannnya, yang ditampilkan dalam foto yang artistik. Buku ini memungkinkan Vera Wang untuk mengekspresikan falsafah dan kepribadian rancangannya secara sekaligus, sehingga kemudian melambungkannya 
menjadi perancang gaun pengantin yang sukses.

Kesuksesan yang diantarkan oleh komunikasi getok tular juga terjadi di Green Gear Cycling (Kotler, Armstrong: 2001), perusahaan kecil yang memproduksi sepeda dengan merek Bike Friday secara customized, atau sepeda diproduksi sesuai dengan permintaan konsumen. Komunikasi getok tular berkembang di antara para pengguna sepeda tersebut, karena mereka menerapkan strategi pelanggan sebagai pewarta penting dalam membangun kesetiaan dan merek. Para pelanggan Bike Friday yang setia membentuk hubungan dengan pelanggan yang lain, dan saling berbagi pengalaman menggunakan Bike Friday dalam perbincangan di komunitas mereka. Pentingnya konsumen dalam pandangan para pemasar menyebabkan persaingan produk sejenis menjadi semakin ketat. Maggi dan Knorr (Edwards, Day: 2007), menggunakan pendekatan segmentasi pasar tertentu agar memberikan ketenangan bisnis. Suara konsumen akan didengarkan oleh berbagai pemasar merek yang berbeda, dalam nada yang sama, masalah yang sama, sehingga menjadi perbincangan bahwa konsumen merupakan muara pasar yang harus dicermati. Pendekatan segmentasi pasar secara tidak langsung juga dianggap penting, karena perkembangan teknologi dan fragmentasi media membuat khalayak sulit di jangkau.

Khalayak sasaran (Laemer dan Simmons: 2007) sekarang tidak lagi hanya mendapatkan sumber informasi dari salah satu media saja. Kehadiran beragam media dan fragmentasi menyulitkan pengiklan untuk menjangkau konsumen. Untuk menjangkau khalayak sasaran diperlukan kreativitas agar mereka mengetahui apa yang seharusnya mereka nikmati dari media. Untuk menarik perhatian, banyak perusahaan menggunakan selebriti sebagai daya tarik dalam berkomunikasi. Dengan melakukan pendekatan menggunakan selebriti, Greg Norman (Knapp: 2008), seorang pegolf profesional terkenal, memiliki perusahaan yang diberi nama: Great White Shark Enterprises, yang berjalan dengan kesuksesan yang cukup signifikan. Greg Norman secara aktif terlibat di semua aktivitas merek yang menggunakan namanya, termasuk rancangan desain lapangan golf, pakaian, anggur, dan pembangunan kompleks residensial. Aktivitas dan keterlibatannya menjadi buah bibir dan menjadi perbincangan sehingga dukungan dan keterlibatan pihak-pihak ini membuatnya memiliki reputasi baik, untuk mendapatkan dukungan keuangan dari perbankan dan konsumen. Konsumen adalah individu yang harus dipahami, sehingga lebih memudahkan dalam usaha pemasar untuk memenuhi harapan, keinginan, dan kebutuhannya.

Volkswagen (Scott: 2007) menggunakan pendekatan keinginantahuan konsumen untuk memasarkan dan berkomunikasi dengan khalayaknya. Pendekatan ini dilakukan dengan menciptakan satu situs jejaring maya di MySpace, sehingga memungkinkan para anggota jejaring dapat saling berinteraksi untuk menciptakan perbincangan seperti halnya komunikasi dari mulut ke mulut sehingga tercipta persahabatan secara online. Melalui jejaring Volkswagen membangun komunikasi yang mengadopsi aspirasi pemasar, pengguna, dan khalayak sasaran, sehingga terjalin suatu hubungan di antara ketiganya. Hubungan menjadi salah satu mantra yang menjadi acuan dalam pemasaran. Pendekatan hubungan individual (Arens, Weigold, Arens: 2008) menjadi strategi untuk menciptakan pelanggan yang loyal terhadap merek dengan menciptakan, mempertahankan serta meningkatkan jalinan hubungan jangka panjang dengan pelanggan, melalui pertukaran informasi yang saling menguntungkan antara pemasar dan pelanggannya. Kimberley Clark (Kurtz: 2008) menggunakan strategi pendekatan pengendalian konsumen melalui pemasaran interaktif untuk mengontrol jumlah dan jenis dari keterangan pembeli, dan pelanggan. Internet menyediakan akses langsung untuk mendapatkan keterangan kunci tentang produk pada saat konsumen menginginkannya. Pemasaran interaktif memungkinkan pemasar dan konsumen untuk saling menyesuaikan komunikasi mereka.

Adidas (Kirby, Marsden: 2006) melakukan pendekatan koneksitas melalui pemasaran viral (viral marketing), pemasaran lisan (buzz marketing) dan pemasaran komunikasi getok tular (words of 
Terakreditasi Dirjen Dikti SK No. 56/DIKTI/Kep/2005

mouth). Pemasaran viral, melakukan koneksitas yang terkait secara 'online', pemasaran lisan mempergunakan sarana tradisional atau 'offline' koneksi getok tular dengan penyampaian pesan secara berantai lisan, dan memanfaatkan koneksitas para individu sebagai media. Melalui aktivitas ini, Adidas membantu para penggemarnya untuk menggunakan produk Adidas dan menyebarluaskan tentang merek favorit mereka itu. Penyebarluasan merek dan perbincangan dapat dilakukan dengan memanfaatkan Blog.

Penjahit English Cut (Wright: 2006) menggunakan Blog yang dibuat oleh para CEO, eksekutif, dan pemilik bisnis untuk menjadi ajang untuk memaparkan hal-hal yang ingin diketahui para konsumen, meskipun tetap netral sebagai perwakilan dari sudut pandang seorang blogger. Blog merupakan salah satu cara untuk merengkuh kesempatan dalam membentuk pendapat umum, berbicara langsung dengan para pelanggan, dan menangani masalah-masalah yang sedang terjadi dan yang berkaitan kepada industri dan perusahaannya. Termasuk pencarian solusi bagi masalah-masalah sosial. Untuk menyelesaikan sebuah dilema sosial, seseorang haruslah berkomunikasi, baik dalam laboratorium maupun dalam kehidupan. Membahas suatu dilema pada akhirnya akan membentuk sebuah identitas grup, yang akan meningkatkan perhatian akan kesejahteraan bersama. Penyelesaian dilema dapat dilakukan dengan menggunakan strategi pendekatan dialogis. Pendekatan komunikasi dialogis (Myers: 2008) merupakan strategi yang mampu mengakselerasikan kesepakatan dua pihak yang bertikai. Komunikasi dialogis tersebut memungkinkan terbangunnya kerjasama kedua belah pihak yang sedang bertikai, sehingga secara bersama-sama mereka dapat mengatasi masalah dan mencapai tujuan yang menguntungkan semua pihak.

\section{Komunikasi Getok Tular dalam Aktivitas Pemasaran di Indonesia}

Di Indonesia, hampir semua penggemar kopi, mengenal Starbucks sebagai sebuah kedai kopi dengan kesuksesan bisnis yang luar biasa. Setiap hari para pengunjung kedai tersebut, dengan sabar berdiri dalam antrian menanti giliran untuk memesan segelas kopi. Setelah mendapatkan giliran, di depan kasir mereka memesan dan membayar pesanannya dan mendapatkan bukti pembayaran. Setelah itu, mereka berpindah ke sudut penyediaan pesanan, berdiri dan menunggu sejenak untuk mendapatkan pesanannya. Mereka akan mendapatkan minuman pesanannya, yang mereka tukar dengan bukti pembayarannya. Selanjutnya, minuman pesanan tersebut diserahkan oleh peracik minuman di sudut penyediaan, yang mereka bawa sendiri-sendiri ke tempat penyediaan gula, perasa, untuk diracik ulang ke dalam minuman kopi pesanannya. Kopi yang sudah teracik dengan komposisi yang sesuai dengan kemauan mereka tersebut baru kemudian dinikmati setelah mereka mendapatkan tempat duduk di dalam kedai atau minuman tersebut mereka minum sambil berjalan keluar meninggalkan kedai Starbucks.

Komunikasi getok tular mengantarkan Starbucks menjadi bahan perbincangan dan kemudian menjadi pilihan para individu untuk bertemu, berbincang lebih sekadar dari memeroleh manfaat dan menikmati kopi. Sebagai bagian dari jaringan kedai berkelas dalam penataan interior maupun eksterior, Starbucks di Jakarta dan kotakota besar lainnya di Indonesia mengesankan sebagai tempat nyaman untuk menikmati kopi dan bertemu dengan relasi bisnis.

Starbucks berhasil membujuk orang-orang yang masuk ke kedai Starbucks untuk melihatlihat dan kemudian berhasil menjual barang dagangannya. Mereka bukan lagi datang untuk menikmati secangkir kopi, namun mereka juga datang untuk bersedia menunggu giliran untuk dilayani dan meracik minumannya sendiri, sementara di kedai kopi yang lain mereka dengan santai dapat memesan minumannya dan dilayani. Mereka tidak lagi sekadar menikmati kopi, tetapi juga sebagai gaya hidup menikmati kopi dengan melakukan antrian, bukan saling mendahului seperti halnya bus kota ketika beraksi di jalan raya.

Starbucks berhasil mengubah kebiasaan pola 
minum kopi menjadi sesuatu pengalaman yang berbeda, memberikan kenyamanan, mengubah rutinitas, dan sebuah tempat yang membentuk jaringan komunitas yang saling berkumpul, dan saling interaksi dan membentuk jaringan. Jaringan menyatakan struktur kelompok dengan memfokuskan saluran yang dipakai oleh individu ketika mereka secara langsung berkomunikasi dengan individu lainnya (Fisher,1986). Starbucks menjadi buah bibir, menjadi bahan perbincangan.

Beberapa ilustrasi yang menggambarkan bahwa komunikasi getok tular mengantarkan popularitas merek (produk) juga berada di sekitar kita. Kedai 'kaget' di jalan Riau dengan nama Nasi Kalong yang buka usai magrib, mengundang antrian panjang untuk sekadar menikmati nasi beras hitam dan lauk pauk sederhana secara prasmanan. Belasan pengunjung mengambil bagian dalam antrian secara tertib untuk menunggu giliran mengambil hidangan yang tersedia, dan kemudian langsung membayarnya di kasir.

Di Cikapundung, warung makan Ceu Mar yang mulai buka di sekitar jam 21:00-an, menjadi tumpuan banyak orang untuk menikmati hidangan makan malam hingga dini hari. Mereka melakukan antrian panjang dengan sabar sebelum pemesanan makanan yang dilayani langsung oleh Ceu Mar. Puluhan bangku-bangku plastik dengan meja makan terbatas yang tersedia di sana, rupanya tidak cukup untuk menampung orang-orang yang ingin makan secara bersamaan. Banyak pengunjung melakukan dua kali antrian: menunggu giliran memesan makanan, dan menunggu giliran untuk mendapatkan bangku untuk makan sambil duduk. Beberapa pengunjung bahkan lebih suka makan di dalam mobil mereka.

Di Pasar Cihapit, Bandung masakan rumahan Mak Eha menjadi bahan perbincangan. Semua hidangan Mak Eha dengan kesederhanaannya berhasil menampilkan kualitas masakan 'rumahan' yang menggugah selera. Perkedel, misalnya, daging sapi cincang yang menyatu dengan kelembutan kentang menjadi salah satu hidangan yang terjaga kualitasnya selama puluhan tahun. Melalui komunikasi getok tular, para pecinta makanan yang, bahkan, datang dari luar kota
Bandung mencicipi makanan yang disajikan Mak Eha ini. Berbicara tentang perkedel, di kawasan Stasiun Bandung juga terdapat perkedel yang dikenal sebagai perkedel 'Bondon' yang sangat laku dan dijual hanya mulai dari tengah malam. Banyak orang rela bersusah payah melakukan antrian untuk menunggu giliran membeli perkedel tersebut.

Masih di Bandung, Kingsley menyajikan sajian batagor di pinggir jalan Bungsu. Ribuan batagor setiap hari digoreng di tempat itu dan sebagian besar dibeli untuk disantap di tempat dan sebagian dibawa pulang. Katanya, Batagor ini sangat istimewa, karena proses pembuatannya menggunakan bahan-bahan berkualitas tinggi, seperti iklan tenggiri pilihan. Daging ikan tenggiri pilihan yang dicincang halus dan dipadukan dengan sagu berkualitas serta rempah-rempah membuat batagor tersebut setelah digoreng dalam minyak panas menjadi kenyal dan gurih. Menurut pemilik yang kadang merangkap sebagai juru masak batagor tersebut, pembelinya sebagian besar dari Jakarta. Melalui komunikasi dari mulut ke mulut kelezatan batagor Bandung merambah ke Jakarta. Melalui komunikasi getok tular, orang-orang Jakarta menjadi wisatawan domestik, mereka berwisata kuliner ke Bandung untuk menikmati hidangan sehari-hari yang nampaknya sederhana.

Hidangan sederhana sejenis bolu kukus beraroma coklat yang dikenal sebagai brownies kukus Amanda produksi Bandung, juga tampak popular kalangan komunitas di Jakarta. Popularitas brownies Amanda beredar di kalangan komunitas, karena peran komunikasi getok tular, terutama, pada saat para individu berinteraksi sosial seperti kebiasaan untuk berkumpul bersama-sama dalam sebuah komunitas. Somad, seorang sutradara film yang aktif berkeliling Indonesia untuk pengambilan gambar dengan sejumlah crew film mengetahui brownies kukus Amanda karena direkomendasikan oleh teman-teman di lingkungannya. Teman-teman di lingkungannya ini menyarankan agar brownies kukus Amanda dijadikan sebagai buah tangan dari Bandung, meskipun sebenarnya ia sendiri belum pernah mencobanya. "Belum pernah coba brownies kukus Amanda, tapi denger-denger 
direkomendasikan oleh temen-temen sebagai oleholeh dari Bandung," jelas Somad.

Seorang konsultan pemasaran di Jakarta, sebut saja Sutedjo, mengetahui brownies kukus Amanda, karena buah percakapan dengan istri dan temanteman istrinya, meskipun sebenarnya ia sendiri secara pribadi tidak menyukai brownies kukus tersebut. Dalam pandangannya brownies kukus adalah semacam bolu kukus atau penganan padat yang terbuat dari tepung, gula, telur, coklat bubuk, dan perasa lainnya yang dipersepsikan sebagai roti yang nyaris tidak sempurna pembuatannya. "Istri saya dan temen-temennya membicarakan brownies kukus Amanda, meskipun sebenarnya saya secara pribadi, tidak menyukai bolu kukus yang menurut saya adalah roti yang bantet," ujar Sutedjo.

Komunikasi getok tular bukan saja hanya berpengaruh pada permasalahan kuliner, namun juga merambah ke handphone (HP), seperti Blackberry yang kini melambung di kalangan pengguna HP sejak kemunculan pertama kali di pasar yang sudah menarik perhatian banyak orang. Popularitas yang berkembang dari mulut ke mulut, membuat Blackberry dalam setahun terakhir ini menjadi topik perbincangan yang menarik di kalangan masyarakat pengguna HP di Indonesia. Semakin sering konsumen memperbincangkan Blackberry, semakin tenarlah Blakberry.

Ketenaran Blackberry utamanya diperbincangkan sebagai perangkat yang mengantarkan konsumen pengguna memasuki sebuah dunia tersendiri, yang mampu menyalurkan kesibukan untuk saling berkomunikasi di setiap saat. Kemampuan untuk menyalurkan keinginan untuk saling berkomunikasi tanpa batas waktu ini, secara langsung atau tidak langsung mengubah denyut aktivitas hidup masyarakat.

Hampir semua pengguna HP memperbincangkan Blackberry memperbincangkan Blackberry sebagai sebuah HP bergengsi dan pintar yang mengedepankan fitur messaging. BlackBerry memang termasuk golongan smartphone, yang memiliki koneksi data nirkabel, browser internet dan personal data assistant (PDA). Tetapi, BlackBerry memiliki beberapa fitur dan perangkat yang membedakannya dengan smartphone atau PDA phone lain. Blackberry menerapkan fitur e-mail, messaging, dan internet sebagai fitur utama diterima pasar. Kemampuan untuk mengakses e-mail di mana saja sejalan dengan kebutuhan masyarakat luas. Blackberry sebagai perangkat yang terhubung langsung dengan server membuat pengolahan pengaksesan e-mail dan messaging, menjadi lebih mudah. Dengan sistem langsung seperti ini pesan e-mail dapat diterima dan dibuka lebih cepat oleh perangkat Blackberry, karena sudah diolah oleh server agar sesuai dengan kemampuan perangkat. Fitur, fungsi, bentuk, dan tampilannya beda, membuat Blackberry menjadi sebuah fenomena dalam beberapa tahun terakhir ini di kalangan profesional. Penggunaan Blackberry, menurut mereka, dapat disebut sebagai sarana untuk bersosialisasi di dalam lingkungan mereka dan meningkatkan produktivitas masyarakat. Menurut mereka, perangkat Blackberry dapat membantu para profesional bekerja lebih cepat di setiap waktu, tanpa harus dibatasi dalam jam kerja.

\section{Komunikasi Getok Tular sebagai Sarana Pengantar Pesan}

Komunikasi getok tular lebih dari sekadar dapat membangun hubungan dalam pemasaran secara horisontal, malah mampu membangun hubungan secara vertikal. Komunikasi getok tular mampu menyesuaikan dengan perubahan, karena pesan yang disampaikan dapat diubah selaras dengan perubahan tersebut. Pesan yang disampaikan relatif tanpa medium yang konkret, hanya melalui perbincangan dari mulut ke mulut, membuat komunikasi getok tular menjadi ajang yang efektif sebagai pengantar pesan untuk membentuk dan memperpanjang reputasi merek, serta efisien menjangkau pasar sasaran.

Khalayak sasaran secara tidak sadar mungkin melihat beberapa hal, mengabaikan yang lain, dan berpaling lagi dari yang satu ke yang lain. Setiap faktor ini dapat membantu meningkatkan atau mengurangi kemungkinan bahwa suatu stimulus akan dirasakan. Stimuli pemasaran meliputi banyak 
variabel yang memengaruhi persepsi khalayak, seperti keadaan produk, ciri fisiknya, rancangan produk, merek, ataupun pengaruh periklanan di media cetak, televisi, dan sebagainya.

Komunikasi getok tular mungkin semata-mata pemasaran secara lisan; mungkin melengkapi iklan di televisi, mungkin melengkapi radio, mungkin melengkapi berbagai media yang bisa menggabungkan hal-hal yang tradisional dan nontradisional. Namun, tujuan komunikasi getok tular adalah mencetuskan pesan lebih lanjut secara lisan dan menjadi perbincangan melebihi pesan yang jelas itu. Komunikasi getok tular adalah penyebarluasan pesan melalui pembicaraan maupun pemberitaan di media tentang merek (Hughes, 2005). Penyebarluasan ini, seperti yang dilakukan oleh aktivitas pemasaran (marketing), pada akhirnya memungkinkan terciptanya loyalitas terhadap merek (produk) yang diperbincangkan.

Perbincangan suatu merek (produk) pada dasarnya berkaitan dengan pembahasan pesan, khususnya dengan mengontrol efektivitas pesan berkaitan dengan faktor fisiologis dan perekayasaan. Agar efek pesan tetap dapat dikontrol, diperlukan adanya perekayasaan pengontrolan efek pesan. Perekayasaan efek pesan dimungkinkan karena adanya kelebihan dan kekurangan setiap aktivitas komunikasi. Komunikasi massa, misalnya, memiliki keunggulan untuk melakukan penetrasi pesan ke masyarakat luas melalui daya jangkau media tersebut. Komunikasi getok tular adalah komunikasi interpersonal yang merupakan aktivitas penyebaran informasi dari mulut ke mulut yang menarik perhatian konsumen dan bahkan media sampai pada akhirnya mereka membicarakan merek produk atau perusahaan menjadi sesuatu yang menyenangkan, mengagumkan, dan bernilai. Perbincangan sebuah pesan dalam komunikasi getok tular akan menjangkau khalayak sasaran dengan efektif: tepat sasaran, dalam batasan biaya yang efisien: tepat guna. Secara sederhana, komunikasi getok tular mengawali perbincangan yang akan menyebar luas. Komunikasi getok tular tidak sama dengan iklan di televisi, penjualan lewat pos, atau radio. Semua yang disebutkan itu adalah medium, atau sarana. Sedangkan komunikasi getok tular berkaitan dengan tujuan (ends).

Komunikasi getok tular mengomunikasikan konvensi baru ke pasar utama dengan cara tidak dapat dilakukan media lain (Wipperfurth, 2005), karena komunikasi getok tular mempunyai beberapa karakteristik yang sudah lama ditinggalkan media tradisional yaitu: perhatian, pembelajaran, kredibilitas, keakraban, dan autentisitas.

Perhatian. Komunikasi getok tular tidak terlihat, terdengar, atau terasa seperti halnya ratusan atau ribuan iklan konvensional yang menyerbu khalayak setiap hari. Komunikasi getok tular hanya merupakan perbincangan lisan maupun tertulis secara elektronik (viral, blog dst.) mengenai topik yang dibutuhkan khalayak pada saat yang tepat. Perbincangan menjadi hangat dan menarik karena topik yang dibicarakan bersifat terkini dan dibutuhkan oleh khalayak, dan oleh karena itu mendapatkan perhatian dari khalayak.

Pembelajaran. Getok tular sebagian besar bekerja pada tingkat bawah sadar, sehingga banyak khalayak tidak mengetahui bahwa mereka mengetahui sebagian besar hal yang mereka ingin ketahui. Proses pembelajaran terjadi pada pikiran bawah sadar dan di tingkat itulah komunikasi getok tular sangat efektif. Melalui komunikasi getok tular, khalayak mengadopsi secara luas norma-norma baru melalui pembelajaran dari komunikasi getok tular dan melakukan apa yang mereka pikir harus dilakukan.

Kredibilitas. Konsumen menganggap rekomendasi pribadi seperti suami/istri/pasangan; teman; rekan kerja; lebih dapat dipercaya dibandingkan dengan pesan melalui media tradisional. Saling kenal antara sumber pesan dan penerima pesan menumbuhkan saling percaya dan saling menghargai. Keduanya akan berusaha untuk saling menjaga demi kebaikan mereka sendiri.

Keakraban. Komunikasi getok tular memanfaatkan efek "halo". Jika si pembawa pesan adalah teman, maka penerimaan pesan tersebut lebih akrab dan lebih dihargai. Topik yang diperbincangkan meskipun mengenai manfaat atau bahkan pengalaman pengunaan produk atau jasa 
karena berasal dari sumber yang dikenal, penerima pesan cenderung menerima isi perbincangan tersebut sebagai sesuatu yang sangat akrab, tidak berjarak seperti halnya sebuah iklan dengan khalayak sasaran. Khalayak cenderung untuk memandang isi perbincangan sebagai bingkisan dari seorang teman untuk kebaikan pertemanan itu sendiri.

Autentisitas. Perbincangan mengenai manfaat suatu produk atau jasa atau pengalaman pengunaannya merupakan penghargaan bagi pemasaran produk atau jasa tersebut. Perbincangan mengenai topik tersebut bukanlah yang mudah untuk direkonstruksi atau dijadikan tolok ukur. Jika ini terjadi maka hal itu akan membuat para pesaing merek iri, karena hal itu adalah indikasi tak terbantahkan bahwa pasar menganggap merek tersebut autentik. Merek menjadi sesutu yang istimewa dan tidak dapat digantikan.

Ketika sebuah observasi yang dilakukan untuk mengetahui sumber informasi yang memengaruhi pembelian konsumen terhadap merek (produk), ternyata bahwa acuan mereka adalah komunikasi dari teman ke teman atau words of mouth. Perbincangan dengan para pemilik Blackberry baru-baru ini menunjukkan bahwa hampir seluruh pemakai perangkat tersebut mengenal Blackberry melalui komunikasi dari mulut ke mulut dengan para pemakai potensial lainnya. Hal yang sama terjadi dengan para pecinta Starbucks, wisata kuliner dengan mengunjungi kedai-kedai makan di Bandung.

\section{Komunikasi Getok Tular sebagai Ajang Pengantar Popularitas}

Komunikasi getok tular dapat dikembangkan sebagai saluran referensi untuk jaringan bisnis, seperti halnya iklan. Komunikasi getok tular berpeluang untuk berfungsi sebagai ajang untuk mempopularkan merek (produk). Para profesional promosi akan lebih sering mendorong klienkliennya untuk bertindak melalui perbincangan komunikasi getok tular yang memiliki kredibilitas yang tinggi, sehingga mendorong tindakan untuk membeli produk, jasa, atau gagasan setelah menjadi bahan perbincangan dalam suatu komunitas. Khalayak sasaran lebih percaya kepada orang yang mereka kenal, dan hargai. Dalam perbincangan secara personal perbincangan akan lebih akrab yang mencerminkan hubungan pribadi yang akrab pula. Komunikasi getok tular terjadi pada saat khalayak sasaran membutuhkannya dan pada umumnya mereka sangat berminat pada topik yang diperbincangan. Secara tradisional, komunikasi getok tular terjadi di kampus, bar, kantin, kafe, atau bahkan di dalam suatu kelompok arisan.

Anggota komunitas ini terdiri atas para individu yang berperan ganda sebagai penerima informasi, pemakai produk yang terpuaskan, kemudian bertindak sebagai komunikator yang kemudian menyebarluaskan informasi diterimanya kepada konsumen lainnya. Penyebaran informasi dalam perbincangan ini dapat membangun sebuah pencitraan merek. Komunikasi personal memberikan peluang tentang pesan-pesan yang disampaikan, akan lebih cepat diterima dan diberi tanggapan oleh khalayak tertentu yang dituju. Juga akan terjadi dialog, sehingga pesan dapat disampaikan secara lebih komprehensif dengan umpan balik (feedback) yang cepat dan lebih akurat, terutama jika dilakukan melalui komunikasi getok tular.

Para anggota komunitas membentuk jaringan informal secara eksklusif tanpa melalui forum resmi, menyebar dari satu individu ke individu lainnya, dari satu komunitas ke komunitas lainnya melalui komunikasi getok tular. Komunikasi getok tular tumbuh subur dalam masyarakat kolektivis, seperti di Indonesia. karena dalam masyarakat kolektivis, diri (self) tidak bersifat unik atau otonom, melainkan lebur dalam kelompok (keluarga, klan, kelompok kerja, sukubangsa, bangsa, dsb.). Karena itu, perilaku individu juga sangat dipengaruhi kelompoknya. Dalam budaya kolektivis, individu tidak dianjurkan untuk menonjol sendiri (Mulyana, Rakhmat: 2006).

Terikat kuat dengan kelompoknya, manusia kolektivis sangat peduli dengan peristiwa-peristiwa yang menyangkut kelompoknya. Mereka membicarakan pernikahan, perselingkuhan, perceraian artis secara terbuka. Semua saluran televisi menyiarkan acara yang berisi gosip setiap 
hari dan mendapatkan rating yang tinggi. Pemirsa menyimak acara tersebut dan kemudian memperbincangkannya kembali ketika mereka sebagai masyarakat kolektivis melakukan hal-hal yang mereka senangi, yaitu saling mengunjungi, berkumpul bersama, dan saling bertukar pesan. Dalam kondisi masyarakat kolektivis seperti di Indonesia komunikasi getok tular akan tumbuh dengan subur dan berpotensi untuk dikembangkan sebagai saluran yang berfungsi sebagai ajang untuk membentuk dan mengembangkan popularitas merek (produk)

\section{Daftar Pustaka}

Arens, William F., Michael F. Weigold, Christian Arens. 2008. Contemporary Advertising. New York: McGraw-Hill

Edward, Helen, Derek Day. 2007. Creating Passion Brands, how to build emotional brand connection with customers. London: Kogan Page

Fisher, B. Audrey. 1986. Teori-teori Komunikasi, terjemahan Soejono Trimo, penyunting Jalaluddin Rakhmat. Bandung: Remaja Rosdakarya

Haig, Matt. 2003. Brand failures, the truth about the 100 biggest branding mistakes of all times. London: Kogan Page Ltd.

Hughes, Mark. 2005. Buzz Marketing, get people to talk about your stuff. New York: Portfolio

Kirby, Justin, Paul Marsden. 2006. Connected Marketing, the viral, buzz and word of mouth revolution.Jordan Hill, Oxford: ButterworthHeinemann

Knapp, Duane E. 2008. The Brand Promise. New York: McGraw-Hill

Kotler, Philip. 2003. Marketing Management 11th edition, Upper Saddle River, New Jersey: Pearson Education Inc.
Kotler, Philip, Gary Armstrong. 2001. Principles of Marketing 9th edition. Upper Saddle River, New Jersey: Prentice Hall Inc.

Krech, David, Richard S. Crutchfield, Egeron L. Ballachey: 1962. Individual in Society, a text book of Sosial Psychology. Tokyo: McGrawHill Kogakusha.Ltd.

Kurtz, David L. 2008. Principles ofContemporary Marketing. Mason, Ohio: Thomson SouthWestern

Laemer, Richard, Mark Simmons. 2007. Punk Marketing. New York: HarperCollin Publishers

Littlejohn, Stephen W., Karen A. Foss. 2008. Theories of Human Communication 9thedition. Belmont, CA: Thomson Higher Education

Mulyana, Deddy, Jalaludin Rakhmat. 2006. Komunikasi AntarBudaya, Panduan berkomunikasi dengan orang-orang berbeda budaya. Bandung: Rosdakarya

Morgan, Adam. 1999. Eating the Big Fish. How challenger brands can compete against brand leaders. New York: John Wiley \& Sons, Inc.

Myers, David G. 2008. Social Psychology, New York: McGraw-Hill

Scott, David Meerman. 2007. The New Rules of marketing \& PR. Hoboken, New Jersey: John Wiley \& Sons, Inc.

Schiffman, L.G. 2001. Consumer Behaviour 2nd edition. Sidney: Prentice Hall

West, Richard, Lynn H. Turner: 2007. Communication Theory, analysis and application 3rd edition. New York: McGraw-Hill

Wipperfurth, Alex. 2005. Brand Hijack, marketing without marketing. New York: Portfolio

Wright, Jeremy. 2006. Blog Marketing, Revolutionary New Way To Increase Sales, Build Your Brand, and Get Exceptional Results. New York: McGraw-Hill Companies 